\title{
THE IMPACT OF ENTREPRENEURIAL ORIENTATION ON SMES PERFORMANCE IN GHANA: THE ROLE OF SOCIAL CAPITAL AND GOVERNMENT SUPPORT POLICIES
}

\author{
Solomon Gbene Zaato ${ }^{{ }^{*}}$, Mohammad Ismail ${ }^{2}$, Sathiswaran Uthamaputhran ${ }^{3}$, \\ Wilberforce Owusu-Ansah ${ }^{4}$ \\ ${ }^{123}$ Faculty of Entrepreneurship and Business, Universiti Malaysia Kelantan, Malaysia \\ ${ }^{4}$ Department of Marketing \& Corporate Strategy, Kwame Nkrumah University of Science and Technology, Ghana \\ Corresponding Author; Email: ${ }^{1 *}$ zagso2012@gmail.com, ${ }^{2}$ mohammad.i@umk.edu.my, ${ }^{3}$ sathiswaran@umk.edu.my, \\ ${ }^{4}$ woansah@gmail.com
}

\begin{abstract}
The primary purpose of this study was to propose a conceptual framework on the impact of entrepreneurial orientation (EO) on SMEs performance in Ghana: The role of social capital (SC) and government support policies (GSPs). The study reviewed existing literature pertaining the five dimensions of EO and used measures of SC, and GSPs in relation to SMEs performance in Ghana. This study would be anchored on two theories thus the resourcebased view and the social capital theories stressing the need for SMEs to focus more on their unique resources that existed within their social network relations. The study would further provide new insight to practitioners to understand and appreciate the role of SC and GSPs on SMEs performance.
\end{abstract}

Keywords: Entrepreneurial orientation, social capital, government support policies, resource base view theory, social capital theory.

\section{Introduction}

The performance aims to determine how SMEs achieve an objective, standard or target. In business or managerial research, many definitions exist depending on the discipline or area of study and relate performance to the value that customers and other stakeholders derive from a firm (Gathungu, Aiko, \& Machuki, 2014). Efficiency and effectiveness have also become a popular measure of performance in manufacturing and services areas like finance and marketing. In the manufacturing sector, authors like (Arafah, Batara, \& Hady, 2018; Kombo, K'Obonyo, \& Ogutu, 2015) used five vital measurements consisting of reliability, quality, product price or cost, and flexibility to ascertain the performance of a business. To entrepreneurs, performance is linked with profitability, growth, market value, return on capital, value addition, and customer satisfaction and retention and is often operationalised by researchers (Mihaela, 2017; Aladejebi \& Olufemi, 2018).

Globally, SMEs are not just considered as the engines of economic growth but the fuel or lubricant that keep developed and developing economies on their toes running without a halt. However, their failure rate of SMEs is higher compared to large firms (Bloch \&
Bhattacharya, 2016; Lo, Wang, Wah, \& Ramayah, 2016). Data show that three out of every five SMEs die before their 5th anniversary and eight out of ten potential entrepreneurs are discouraged from starting their dream venture every year in several countries of the world (Hoque, Siddiqui, Awang, \& Baharu, 2018).

Thus, the abysmal performance of SMEs in Ghana and lack of international exposure due to the growing external competition prevents them from strengthening their market share (Asare, 2014). They also lack the ability to expand and create more jobs, conservative about their growth and employment creation prospects, with almost a third of entrepreneurs not ready to employ anyone. Again, only 47\% SMEs are prepared to hire from one and five staffs in five years (Global Entrepreneurship Monitor, 2013), thus, a sign that Ghanaian SMEs are not performing well to contribute to the economic growth of the country.

High business failure rate exists among Ghanaian SMEs. Regarding that, the Minister for Business Development, Ibrahim Awal Mohammed reported that 75 per cent of firms fail within the first three years, with those that can surpass three years within ten years of operation and need serious efforts by entrepreneurs to address it (Mohammed, 2017). Again, in 2018, 
Mohammed, reiterated that for only 15 per cent of firms to go beyond three to five years is unacceptable and encouraged collaboration from industry and academia to train young graduates with entrepreneurship skills (Mohammed 2018). This support Alimo's (2015) earlier study that most Ghanaian SME owners lack the requisite entrepreneurial skills to enable their firms to survive beyond five years.

Another current issue that affects SMEs performance in Ghana is the collapse of several banks and microfinance institutions (MFIs) by the Bank of Ghana (BOG) to stabilise the banking and financial sector. This led to the merger and collapse of some banks and MFIs and is affecting the performance of SMEs (Boateng et $a l ., 2016$ ). This further pose a negative perception about Ghanaian entrepreneurs where consumers and investors are not trusting SME owners and resorted to some spending money on foreign-owned products instead of local ones making SMEs less competitive (Mensah, 2018).

More so, SMEs in Ghana cannot also absorb the cost of human resources and training, network with other business partners to make use their resources to meet other financial demands like large business do (Egena, Wombo, Theresa, \& Bridget, 2014). Are SME owners in Ghana, not EO enough to respond to the turbulent market demands, create a market niche for themselves with creativity to overcome difficult obstacles with innovative products and services in order to grow and launch new firms that will perform to expectation or what? (Pranowo, Mulyadi, Siregar, \& Hendayana, 2018; Mahmoud, 2011; Alimo, 2015), since EO is widely acclaimed as the sole construct for SMEs performance, an indicator of their growth and performance and help SMEs to withstand turbulent market environs (e.g. Palmer, Niemand, Stöckmann, Kraus, \& Kailer, 2019; Omisakin, Nakhid, Littrell, \& Verbitsky, 2016; Semrau, Ambos, \& Kraus, 2016; Mason, Floreani, Miani, Beltrame, \& Cappelletto, 2015; Wales, Patel, \& Lumpkin, 2013; Lee, Sohn, \& Ju, 2011). EO will also help SMEs to actively engage in opportunity identification and proper utilisation of resources (Carree $\&$ Thurik, 2005).

Data however agree that there are inconsistencies on the impact of EO on SMEs performance and on whether to use the unidimensional or the multidimensions of EO and most of the studies have also been conducted in USA and UK (e.g. Miles \& Snow, 1978; Lumpkin \& Dess, 1996; Rauch, Wiklund, Lumpkin, \& Frese, 2009; Pett \& Wolff, 2010; Covin \& Wales, 2012; Wales et al., 2013; Dutta, Gupta, \& Chen, 2016; Fadda,
2018). Earlier studies recommended that further studies regarding the impact of EO on SMEs should be conducted in different countries and sectors of the economy for further understanding and interpretation (Rezaei \& Ortt, 2018; Gathenya, Bwisa, \& Kihoro, 2011). Yet, there is less data on EO and SME performance in Ghana (Anlesinya, Eshun, \& Bonuedi, 2015; Hongyun, Kankam, Appiah-Twum, \& Akolgo, 2019).

Further, globalisation has changed the pace of businesses where creativity, innovation, critical and independent managers with good networking skills and alliances are much required than the mere competition with competitors (Hongyun et al., 2019); as a result, firms must adopt good SC network resources in order to survive. And for SMEs to enhance their performance, they need not only financial capital and human capital (business training and management skills), but also, they need to develop, promote and use appropriate forms of SC networks and access government support too (Tundui \& Tundui, 2013).

The SC theory like the resource-based view (RBV) theory that offer SMEs the ability to utilise rare and valuable resources that are difficult for other firms to replicate and substitute (Barney, 1991), and boost their resource base and capabilities (Brush \& Chaganti, 1999). $\mathrm{SC}$ is also vital for entrepreneurial activities as, entrepreneurship is a socio-economic activity that relies on social context and entrepreneurs are also products of their social environs and the existence or lack of social networks affect SMEs performance in acquiring resources, and is a vital resource that no SME can ignore and expect to perform well (Anderson \& Miller, 2003; Kanini \& Muathe, 2019).

Literature affirm that SC impact positively on SMEs performance and help them to outperform their competitors (Acheampong, Odoom, Anning-Dorson, \& Anim, 2018; Agyapong, Agyapong, \& Poku, 2017; Barr, 2000; Boohene, 2018; Ofori \& Sackey, 2010; Chirico \& Salvato, 2008), though some reported negative or no impact at all (Rowley, Behrens, \& Krackhardt, 2000; Lee et al., 2001). However, there is scarce literature in Ghana on EO and social capital (Hongyun et al., 2019). The inconclusive results give room for further studies using SC as a mediating and or moderating variable with other variables in other sectors of the economy and countries (e.g. Roberson \& Williamson, 2012; Uzzi \& Lancaster, 2003; Hongyun et al., 2019). Again, prior studies also recommend the use of mediating and or moderating variables that relate to the internal and external characteristics of SMEs performance to 
further understand the influence of EO on SMEs performance (Lumpkin \& Dess, 1996; Wiklund \& Shepherd, 2005; Wiklund, Patzelt, \& Shepherd, 2009; Mahmood \& Hanafi, 2013; Alembummah, 2015). This study is meant to fill this gap in Ghana by introducing $\mathrm{SC}$ and government support policies as mediating and moderating variables respectively to investigate their effect on EO and SMEs performance.

Proper adoption of EO and SC, together with government support, will also boost SMEs performance. Governments all over the world recognise the significant contributions of SMEs and are promoting their survival. With government support in develop and developing countries to SMEs like India, South Korea, Taiwan and China are reaping massively from the SMEs sector (Kusi, Opata, \& Narh, 2015), South Africa, and the United Arab Emirates which account for their enviable economic status (Onuoha, 2012) but Ghanaian SMEs are not performing well. These countries also experience reduced poverty levels, unemployment, and economic well-being due to the presence of vibrant and reputable SMEs (Onugu, 2005; Eniola \& Entebang, 2015).

Many unsolved questions arise. Why are SMEs performing better in other countries that apply EO, SC, and or with government support but Ghanaian SMEs are not? Are Ghanaian SME owners not EO or they are losing interest in their SC networks instead of making apt use of them to attract government support policies like, subsidise training, easy access to capital/resources, linkages with other partners, and continuous monitoring and evaluation (Stuart, 2000; Tzelepis \& Skuras, 2004; Cai, Jun, \& Yang, 2010; Soares, Moeljadi, Rohman, \& Solimun, 2014) to their advantage or what? Since there is less literature and much is not also felt with the presence of vibrant SMEs and the intended development in Ghana (Akugri, Bagah, \& Wulifan, 2015), hence the use of government support policies as a moderating variable in this study as recommended by Soares et al. (2014).

Based on the above discussed literature and as far as we know, there is no study in Ghana on the impact of SMEs performance in Ghana with the mediating and moderating role of social capital and government support policies. This study therefore seeks to fill this empirical and knowledge gap using all the five dimensions of EO, social capital and measures or indicators of government support policies like, tax reduction, free or subsidise training to SMEs, access to capital and other resources, linkages to market partners, and monitoring and evaluation.

\section{Overview and Relevance of SMEs}

There is no universally accepted definition for the term SMEs. This study define SMEs as, a micro enterprise is define as having 1-5 employees and fixed assets less than 10,000 USD, excluding land and building, small enterprises employing 6-29 with fixed assets not more than 10,000 USD which excludes land and building and those employing from 30-99 as medium enterprises having fixed assets of up to 100,000 USD, and firms that employs more than 100 are considered as large firms (NBSSI) and also agreed with the Ghana Enterprise Development Commission (GEDC) estimated amount of 10 million Ghana New Cedis as the upper limit or value for plant and machinery as summarised by Table 1 .

Table 1

Definition of SMEs based on NBSSI Classifications or Types in Ghana

\begin{tabular}{lll}
\hline $\begin{array}{l}\text { Type of SMEs or } \\
\text { Enterprise }\end{array}$ & $\begin{array}{l}\text { Number of } \\
\text { Workers }\end{array}$ & Value of Firm Assets \\
\hline Micro enterprise & $1-5$ workers & Less or up to US\$ 10,000 \\
Small enterprise & $6-29$ workers & Up to US\$ 10,000 \\
Medium enterprise 30-99 workers & Up to US\$ 100,000 \\
Large enterprise & $\begin{array}{l}100 \text { and more } \\
\text { workers }\end{array}$ & Up to US\$ 1000,000 \\
\hline
\end{tabular}

Source: Abor and Quartey, 2010

\section{Entrepreneurial Orientation}

In this study, entrepreneurial orientation is defined as how entrepreneurial individual(s) or firms are to identify and exploit opportunities using proactiveness, calculated risk-taking, innovativeness, competitiveness and also acting independently or in autonomy in launching new and or innovative products and services with the aim of overtaking their competitors and is vital requirement for SMEs survival and performance (Miller, 1983; Lumpkin \& Dess, 1996).

\section{Dimensions of Entrepreneurial Orientation}

Following the introduction of EO from Miller's (1983) seminal work tapping ideas from earlier scholars (Knight, 1921; Schumpeter, 1942; Kirzner, 1973), its interest has gained momentum in management and research and is also applicable in various fields like economics, psychology, and strategic management (Lumpkin, \& Dess, 1996, 2001; Covin \& Slevin, 1986, 1989, 1991; Fatoki, 2012). With the significant discrepancies in these fields, each field viewed the EO dimensions from a different perspective. These diversities made it more complicated to conceptually develop 
$\mathrm{EO}$, as economists viewed $\mathrm{EO}$ as the process which combines various factors of production that is, land, labour, and capital to increase a firm's performance (Schumpeter, 1942; Miller 1983).

Based on this, two primary constructs of EO emerged; thus; the first one pioneered by Miller (1983), that $\mathrm{EO}$ is a three-factor one-dimensional model consisting of innovation, risk-taking, and proactiveness. According to Miller (1983), SMEs/entrepreneurial firms have to engage in risky ventures, be innovative, and take the lead in reaching their markets (Covin \& Slevin, 1986, 1989, 1991). For Miller, to be an entrepreneurial firm, all the three dimensions, that is, risk-taking, proactiveness, and innovativeness must manifest without which the firm cannot be termed entrepreneurial and by extension, a performing firm (Kusumawardhani, McCarthy, \& Perera, 2009), see Figure 1.

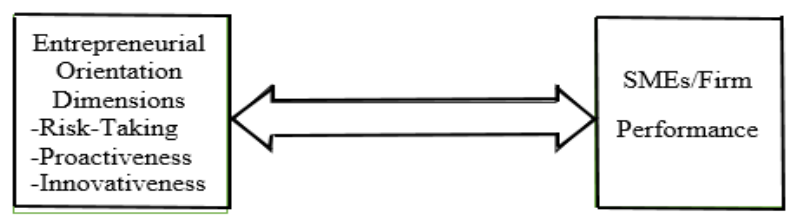

Figure 1. Miller (1983) Three-factor one-dimensional model

The second construct of EO attributed to Lumpkin and Dess (1996), treats EO as a five-factor multidimensional model having competitiveness or competitive aggressiveness and autonomy as additional dimensions to Miller's (1983) model. When introducing this construct, Lumpkin and Dess (1996) used the term competitive aggressiveness to signify Miller's (1983) notion of "beating competitors to the punch." In their view, how SMEs respond to threats is essential in addition to seizing opportunities. The dimension of autonomy, according to the authors, connote strong leadership by creative individuals who act freely without any restrictions.

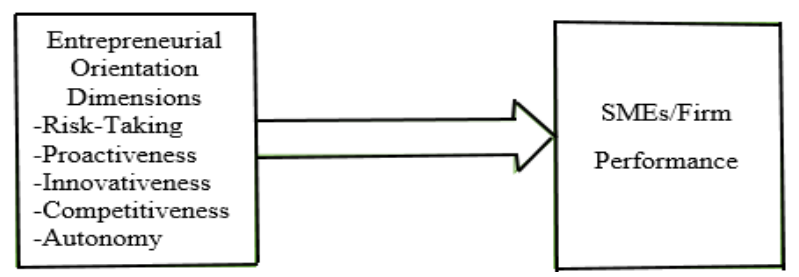

Figure 2. Lumpkin and Dess (1996) five-factor multidimensional model

Contrary to Miller (1983) assertion that all EO dimensions must exist for a firm to be termed entrepreneurial, Lumpkin and Dess (1996) however disagree for all the five EO dimensions to be present as indicated by Figure 2. Studies show that more researches should be conducted using the multidimensional approach as well as expanding the examination of EO dimensions with mediating and moderating variables in different geographical areas or stages of development and sectors of the economy to appreciate how EO affects the performance of SMEs (Gathenya et al., 2011; Rezaei \& Ortt, 2018; Hongyun et al., 2019).

The five EO dimensions have proven to be the most accurate description of the performance of SMEs in determining whether they are succeeding in their performance or not (Lumpkin \& Dess 1996), as well as offer varied results for further interpretations, and help reduce confusing descriptive and normative theorybuilding if all the five EO dimensions are not used (Covin, Green, \& Slevin, 2006; Rezaei \& Ortt, 2018). Below is a brief explanation of the various EO dimensions and their hypothesis for this study.

\section{Innovativeness in SMEs}

Rapid changes in global markets have resulted in rising competition and erosion of value addition and the effectiveness of organizations' products and services (Gunday, Ulusoy, Kilic, \& Alpkan, 2011). Innovativeness is one of the fundamental instruments of SMEs or firms' strategies to develop new ideas leading to new or improved processes, products and or services to penetrate markets, attract and expand market share, and also give SMEs or firms a competitive advantage in response to these changes around them (Landstrom, 2005; Rauch et al., 2009; Lomberg, Urbig, Stöckmann, Marino, \& Dickson, 2017).

Innovation was first recognised by Schumpeter (1942) when he equated it with "creative destruction." In his view, creative destruction is the process in which as a result of wealth creation, it leads to the destruction of existing products/services and market structures by introducing new goods or services which shift resources from existing firms to new firms, thereby giving new firms growth advantage and should be initiated by an entrepreneur (Lumpkin \& Dess 1996).

Previous literature alluded that innovativeness has a significant and positive effect on SMEs performance (Wong, 2014; Heidenreich \& Handrich, 2015; Mamun, Muhammad, \& Ismail, 2017; Bature, Sallehuddin, Rosli, \& Saad, 2018; Acar \& Özşahin, 2018), and as SMEs imbibe innovative spirit, they will be able to respond to the changing market demands, compete 
keenly in the market and also develop new products and services to counteract external market pressure (Miller \& Friesen 1983; Tsao \& Chen 2012; Acar \& Özşahin, 2018).

In related terms, Choi, Kim, Ullah, and Kang (2016) reveal that SMEs with innovative mindset will enhance the growth of new skills and technical knowhow to handle unpredictable market situations effectively. Again, SMEs that adopt a potent EO and are innovative, as well as promote their social ties with other firms, it will make them more creative and innovative in coming out with new products and services (Zahra \& George, 2002). This study, therefore, seeks to examine further the relationship between innovativeness and SMEs performance in Ghana, to affirm or refute the earlier findings and to make recommendations for further studies. Therefore, we hypothesise in the light of the preceding discussion, the hypothesis that:

$H_{1}$ : Innovativeness has a positive effect on SMEs performance in Ghana.

\section{Risk-taking by SMEs}

This refers to the tendency of an individual in a firm to take bold or well-calculated decisions in venturing into already existing or new markets and commitment of resources into firms with unpredictable results, and or are not risk adverse in committing resources to execute a business idea that other SMEs are afraid of (Lumpkin \& Dess, 2006; Walter, Auer, \& Ritter, 2006; Morris, Kuratko, \& Covin, 2008; Nasip et al., 2017). Risk-taking is linked to entrepreneurship since its inception (Lumpkin \& Dess, 1996) and a critical measure of EO when determining the extent of entrepreneurship among SMEs.

Contrary to that, research revealed that SMEs ability to take risks is between low and moderate levels. Those that adopt a modest level of risk-taking achieve high performers compared with those that adopt very low levels of risk-taking (Kreiser, Marino, \& Weaver, 2002; Otieno, Bwisa, \& Kihoro, 2012). This buttressed the generally accepted rule of thumb that, risk-taking SMEs can secure superior growth and long term profitability compared with those that avoid risk (Yang, 2008; Wang \& Poutziouris, 2010; Ahimbisibwe \& Abaho, 2013). This perspective affirmed the rule of the risk-returned theory that, the higher the risk, the higher the return, and is therefore linked with SMEs performance. SMEs that wants to survive cannot entirely alienate themselves from some level of risk-taking and attain desired performance.
On the effect of risk-taking on SMEs performance, there are divergent views. Other studies revealed a positive and significant relationship of risk-taking and SMEs performance (Kosa, Mohammad, \& Ajibie 2018; Wijethunge \& Pushpakumari, 2013; Lim, 2008; Mohammed, Ricardo, \& Harry, 2014), whiles other studies indicated no or negative effect on SMEs performance (Kreiser, Marino, Kuratko, \& Weaver, 2013). This, therefore, require further studies to ascertain these results among Ghanaian SMEs. As a result, we propose to test the hypothesis that:

$\mathrm{H}_{2}$ : Risk-taking has a positive effect on SMEs performance in Ghana.

\section{The Proactiveness of SMEs to Businesses/Market}

Proactiveness is an opportunity-seeking, forwardlooking perspective involve in a firm taking the initiative to introduce new products or services uncommon to their competitors with the aim of setting the pace or taking first steps or having the first mover-advantage in meeting the demands of people under any given situation by introducing new processes or products and or services ahead of their competitors (Miller, 1983; Lumpkin \& Dess, 2001). SMEs of this kind are always striving to be leaders and not reacting to advances of other businesses (Covin \& Slevin, 1986, 1989, 1991), an indication of opportunity recognition and how they are aware and responsive to market signals ahead of competitors (Venkatraman, 1989; Hughes \& Morgan, 2007; Kropp, Lindsay, \& Shoham, 2008; Kusumawardhani et al., 2009).

Extant scholars reported a positive and significant effect of proactiveness on SMEs performance (Ambad \& Wahab, 2013; Tang, Tang, \& Katz, 2014; Uddin, Bose, \& Yousuf, 2014; Amin, 2015; Lomberg et al., 2017; Grant et al., 2017; Bature et al., 2018). Furthermore, studies reported that SMEs 'with high responsive ability' should consider proactiveness as a vital aspect of their business and always strive to have a first-mover advantage over their counterparts in identifying and turning ideas into opportunities (Tang et al., 2014; Anderson, Kreiser, Kuratko, Hornsby, \& Eshima, 2015; Rua, França, \& Ortiz, 2018).

To be proactive, therefore, SMEs should invest on capacity building thus, working on both their material and non-material resources like the human resource capability to be able to identify timely opportunities to satisfy present and future market needs, influence policymakers, set the pace for the market based on their market share (Tang et al., 2014), and adopt technology usage and are also abreast with technological changes (Hao \& Song 2016; Bature et al., 2018). 
Based upon this premise, this study sought to examine the impact of proactiveness on SMEs performance in Ghana, to affirm or refute earlier studies and to make recommendations for further studies. We, therefore, wish to test the hypothesis that;

$H_{3}$ : Proactiveness has a positive effect on SMEs performance in Ghana.

\section{Competitive Aggressiveness in SMEs}

Competitive aggressiveness or competitiveness was introduced in Lumpkin and Dess's (1996) article to emphasis Miller's (1983) view of SMEs striving to "beat their competitors to the punch." Although this view posits that SMEs mainly win customers over their competitors through proactive innovation, literature argued that competitiveness is distinct from proactiveness.

Lumpkin and Dess (1996) reasoned that competitive aggressiveness is "the type of intensity and headto-head posturing that existing and new entrant SMEs often need to compete with their rivals." They clarify that competitive aggressiveness is seen as the intensity of SMEs to marshal efforts to challenge their competitors to enter the market and with the aim to outperform their rivals (Lumpkin \& Dess, 2001). Lyon, Lumpkin, and Dess (2000) viewed competitive aggressiveness as "the tendency of SMEs to assume a combative posture towards rivals and to employ a high level of competitive intensity in an attempt to surpass rivals." This shows that competitive aggressiveness is termed as the number of actions SMEs take and the time it takes to respond to a competitor's action.

The literature revealed that SMEs with rapid response to competitiveness (Chen \& Hambrick 1995; Miller \& Chen, 1994; 1996) and with a total number of actions (Smith, Young, Becerra, \& Grimm, 1996) have good chances of maintaining competitiveness with headto-head confrontation and lead to performance (Shan, Song, \& Ju, 2016), as they compete for demand (Porter, 1985).

Furthermore, literature confirmed that competitive aggressiveness enhanced and as well have a positive effect on SMEs performance (Mahmood \& Hanafi 2013; Lyon et al., 2000; Justine, 2005). This study can depict a positive and significant effect of competitive aggressiveness on SMEs performance in Ghana. We, therefore, posit the hypothesis that:

$\mathrm{H}_{4}$ : Competitive aggressiveness has a positive effect on SMEs performance in Ghana.

\section{Autonomy in SMEs to Business/Work Environments}

Literature of Kusumawardhani et al., (2009) argued that giving independence to everybody in an organization is likely to enhance their entrepreneurial behaviour and improve performance. For instance, if SMEs encourage individuals or a team to bring forward and carry through to completion of an idea or view, the firm can benefit from the independent spirit necessary for pursuing entrepreneurial opportunities. The autonomy which refers to "the ability and will to be selfdirected in the pursuit of opportunities" is an entrepreneurial act (Lumpkin \& Dess 1996).

According to Coulthard (2007), autonomy in EO flourishes when independent-minded people leave their comfortable positions to pursue novel ideas. Autonomy is also a significant factor for improving performance in new or existing SMEs/firms. Autonomy connotes an independent action of members or in group, ensuring that ideas and initiatives are carried out to the end. With this, employees are given the opportunity to achieve a firm's objective through their own creativity and ingenuity without any interference (Arshad, Rasli, Arshad, \& Zain, 2014).

The study showed that autonomy in SMEs varies as a result of the SMEs size, its management style, or the form of ownership. And that, where the owner-manager is the decision-maker, the right of ownership determines the level of autonomy (Lumpkin \& Dess, 1996). In this case, autonomy is determined by the type of ownership or the level to which leadership is centralised and the frequency at which the owners or managers delegate authority. In large firms, autonomy refers to a firm's restructuring through delegation of authority and reduction of vertical structures in management.

Autonomy has been demonstrated in some SMEs by granting freedom and encouraging members to exercise it (Duru, Ehidiamhen, \& Chijioke, 2018). According to Lumpkin and Dess (1996), this involved the use of champions to promote entrepreneurial activity within SMEs. These champions protect new idea creators or creative thinkers of SMEs from the undesirable judgment and treatment and possible resource constraints.

Earlier studies indicated a positive and significant effect of autonomy on SMEs performance (Duru et al., 2018; Justine et al., 2005; Omisakin et al., 2016). Based on the reviewed literature, we can envisage a positive and significant effect of autonomy on SMEs performance in Ghana. Again, the above discussions on the five dimensions of EO, we can conclude that all the 
dimensions of EO have an impact on SMEs performance. We, therefore, pose the following hypothesis:

$H_{5}$ : Autonomy has a positive effect on SMEs performance in Ghana.

$H_{6}$ : EO has a positive effect on SMEs performance in Ghana.

\section{Social Capital}

Social capital theory traced its origin in sociology by authors such as Bourdieu (1977, 1986), Coleman (1988; 1990), Fukuyama (1995), Granovetter (1985; 1995), Putnam $(1993 ; 2000)$ and is applicable to a wide range of social settings like family interactions, geographic, economic development, the performance of businesses, product innovation, entrepreneurship, supply chain management and other related areas of study. It, however, mean differently in various disciplines like sociology, anthropology, politics, economics and entrepreneurship on SMEs and EO studies (Alguezaui \& Filieri, 2010; Salehuddin, 2009).

According to Adler and Kwon (2002), SMEs in for-profit business or social enterprises, can effectively utilise their social capital building because it helps people with good social capital network find jobs (Gedajlovic, Honig, Moore, Payne, \& Wright, 2013; Lin \& Dumin, 1986), helps inter-units resource exchange and product innovation (Tsai \& Ghoshal, 1998) and the creation of intellectual capital (Nahapiet \& Ghoshal, 1998) and reduces turnover rates (Krack-Hardt \& Hanson, 1993).

The SC theory like the resource-based view (RBV) theory that offer SMEs the ability to utilise rare and valuable resources that are difficult for other firms to replicate and substitute (Barney, 1991), and boost their resource base and capabilities (Brush \& Chaganti, 1999). SC is also vital for entrepreneurial activities as, entrepreneurship is a socio-economic that relies on social context and entrepreneurs are also products of their social environs and the existence or lack of social networks affect SMEs performance in acquiring resources, and a vital resource that no SME can ignore and expect to perform well (Anderson \& Miller, 2003; Kanini \& Muathe, 2019).

In this study therefore, social capital refers to how social interaction affects SMEs performance (Al Mamun et al., 2016), and is seen as the actual and potential resources embedded within, available through, derived from the network of individuals or social units and also facilitate knowledge sharing, value creation, boost competitive advantage and performance, and lead to further development of new firms (Abili \& Faraji, 2009).

Again, social capital also helps entrepreneurs to identify opportunities (Bhagavatula, Elfring, Van Tilburg, \& Van De Bunt, 2010), organise resources (Batjargal, 2003), improve social entrepreneurship (Mair \& Marti, 2005), build legitimacy for their business (Elfring \& Hulsink, 2003), lead to an EO in a firm (De Clercq, Dimov, \& Thongpapanl, 2013) and facilitate access to financial and useful information (Omrane, 2015).

Literature affirm that SC impact positively on SMEs performance and help them to outperform their competitors (Acheampong et al., 2018; Agyapong et al., 2017; Barr, 2000; Boohene, 2018; Ofori \& Sackey, 2010; Chirico \& Salvato, 2008), though some reported negative or no positive impact of SC on SMEs performance at all (Rowley et al., 2000; Lee et al., 2001). Similarly, SC has a positive impact on EO and SMEs performance, provide innovative support to small firms, and lead to high performance (Rass, Dumbach, Danzinger, Bullinger, \& Moeslein, 2013; Dato-on, Banerjee, \& Roy, 2018). Yet, there is scarce literature in Ghana on EO and social capital in relation to SMEs performance (Hongyun et al., 2019).

The inconclusive empirical results on SC and on $\mathrm{EO}$ and SMEs performances give room for further studies to use SC as a mediating and or moderating variable with variables in other sectors of the economy and countries as indicated by past studies (e.g. Roberson \& Williamson, 2012; Uzzi \& Lancaster, 2003; Hongyun et al., 2019). Again, the extant literature also recommends the use of mediating and or moderating variables that relate to the internal and external characteristics of SMEs performance to further understand the influence of EO on SMEs performance (Lumpkin \& Dess, 1996; Wiklund \& Shepherd, 2005; Wiklund et al., 2009; Mahmood \& Hanafi, 2013; Alembummah, 2015). This study adapted operationalise measures of SC based on social trust relationships and reciprocal ties that exist within and outside SMEs (Woolcock, 2001; Woolcock \& Sweetser, 2002). Therefore, this study hypothesised that:

$H_{7}$ : There is a mediating effect of Social capital on EO on SMEs performance in Ghana.

\section{Government Support Policies}

In this study, government support policies refer to the creation of an enabling or a business fostering environment the government create with support 
policies or initiatives to help in the growth and performance of SMEs (Hoque \& Awang, 2019; Cai et al., 2010). These policies should be available to every individual irrespective of their party affiliation, ethnicity, religion, educational background or whatsoever that may hinder an individual in accessing them that governments are mandated to deliver to citizens that want to venture into or are already in business.

Although SMEs all over the world have been hyped as the engine and lubricant of economic growth by many policymakers, there is scarce or no available literature in line with this study from developing countries like Ghana (Ntiamoah, Li, \& Kwamega, 2016). Proper adoption of EO and SC, together with government support, will boost SMEs performance. Studies revealed that with government support policies, some developing countries like India, South Korea, Taiwan and China realize significant impact from the SMEs sector (Kusi et al., 2015), and South Africa, and the United Arab Emirates which account for their present enviable economic status (Onuoha, 2012).

Furthermore, it has been reported that strong government support generally implies a firm's good relationship with government officials, who can become critical sources for information. This is because, in many times, the government implements business-friendly policies in specific regions and industries or policies tailored to specific firm sizes or types of ownership. If necessary, it even provides financial support in the form of low-interest loans from state-owned banks to SMEs in order to encourage them to comply with its guidelines (Cai et al., 2010).

In the study of Saberi and Hamdan (2018), it summarised that governmental support policies have a significant moderating effect on the relationship between entrepreneurship and economic growth in the Gulf Cooperation Council (GCC) countries. There are, however, variations on the available literature on the moderating effect of government support policies on EO and social capital regarding SMEs performance. In assessing the effect of EO on firm performance with government support policies as a moderating variable, Soares et al. (2014) revealed that government support policies could not moderate EO on SMEs performance and do not also have a direct moderating effect on SMEs performance. Soares et al. affirmed that with an entrepreneurial fostering environment with government support policies and entrepreneurs making good use of social capital networks among SMEs together with good policies from government like tax incentives to SMEs, sponsoring training programmes for SMEs and the provision of consultancy services to existing and new SMEs will boost the growth and performance of SMEs with more firms emerging. The study also recommended that a study of this kind is needed in different regions and countries for further understanding and interpretation which formed the bases for this study in Africa and Ghana in particular.

Again, extant literature indicated that, as governments provide good policies to SMEs like; free or subsidise training services to improve the human resource capacity of SMEs, making it easier for SMEs to have access to capital and other resources, promotion of partnership or linking SMEs with other partners as well as offering continuous monitoring and evaluation to beneficiary SMEs, it will enhance their performance and Ghana in particular (Tzelepis \& Skuras, 2004; Stuart, 2000; Cai et al., 2010; Soares et al., 2014; Shu, De Clercq, Zhou, \& Liu, 2019).

It has been reported that, with government support policies some develop and developing countries like India, South Korea, Taiwan, and China are reaping massively from the SMEs sector (Kusi et al., 2015), and South Africa, and the United Arab Emirates which account for their present enviable economic status (Onuoha, 2012), but this is not so in Africa and Ghana in particular and there is also scarce literature on government support policies on SMEs performance and competitiveness and much is not also felt with the presence of vibrant SMEs and the intended development in Ghana (Akugri et al., 2015; Eniola \& Entebang, 2015; Ntiamoah et al., 2016).

Finally, with some of the government support policies that governments have been providing to SMEs, this study expects a positive effect on the performance of SMEs in Ghana using measures of government support policies as; free or subsidise training services to improve the human resource capacity of SMEs, access to capital and other resources, linking SMEs to other market partners and monitoring and evaluation services to SMEs. In this study, therefore, we posit the hypothesis that:

$H_{8}$ : There is a moderating effect of Government support policies on EO and social capital on SMEs performance in Ghana.

\section{Performances of SMEs}

SMEs performance is a term that connotes different meanings by researchers. In this study, SMEs performance referred to as its ability to arrive at desired results and activities that are generally accepted by the firm (Gharakhani, \& Mousakhani, 2012). This 
acceptable measure of performance can either be by subjective (financial) and or objective (non-financial) measures or both (Hayat, Latif, Humayon, Ahmed, \& Azeem, 2019). The non-financial or combination is more preferred because, it is at times difficult for SMEs owners to reveal relevant information on their finances through the non-financial measure is not also free from the biases of respondents (Bamfo \& Kraa, 2019).

This study will use financial and non-financial measures to measure the performance of SMEs like; Sales growth, growth in profit, employee growth, turn over, growth in market share, customer satisfaction and retention as indicated by (Dess, Lumpkin \& Covin, 1997), and corroborates (Covin \& Wales, 2012) who posit that researchers are at liberty to choose which measures deemed appropriate for measuring SMEs/firm performance in their study. The measures of performance used in this study further agree with (Hameed \& Ali, 2011; Lysons \& Farrington, 2012; Ong $\&$ Ismail, 2012) who used sales revenue, growth in profits, number of employees, growth in market share and customer satisfaction and retention in their studies.

Finally, this study seeks to fill the discussed theoretical and knowledge gaps based on the RBV and SC theories to assess the impact of EO on SMEs performance in Ghana, the mediating and moderating effect of SC and government support policies in the services and industry sectors which constitute the highest employment and GDP contribution to the economy of Ghana using this research framework as indicated by Figure 3.

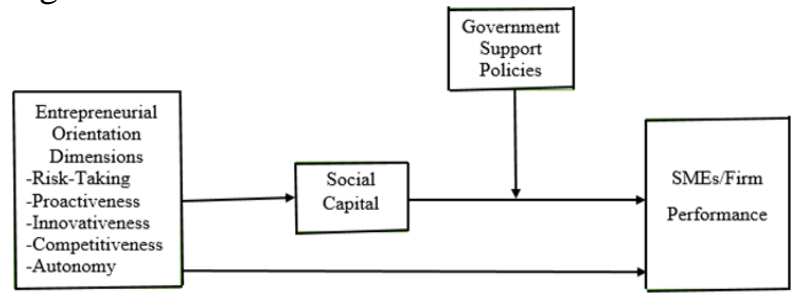

Figure 3. Research framework of the study

\section{Conclusion}

The significance of SMEs cannot be overemphasised and has been alluded by various governments and several stakeholders involved in the SMEs sector of any nation. Much contributions from the SMEs sector is expected from Ghana as a developing country and where the masses are not involved in the formal sector of the economy. Even that, since the government of Ghana, continue to depend on foreign donor countries to fund their developmental projects. For that matter, the government of Ghana should not and cannot overlook the enormous contributions of SMEs. Government is therefore expected to create entrepreneurial fostering environment and business-friendly policies towards the growth and performance of SMEs. This will enhance the economic wellbeing of people as well as boost the economic development of the country in terms of job creation, growth and performance of firms and reduce unemployment in the country. This will intend to make the SMEs sector more vibrant and contribute significantly towards the Gross Domestic Product of the country.

Based on previous studies, this study sought to ascertain the mediating effect of social capital while using government support policies as a moderator to determine its impact on EO and SC on SMEs performance in Ghana. This novel model is also anchored on two theories thus; the RBV and SC theories to explain the need for SMEs to make good use of their unique internal and external resources that exist within their social network relationships.

This study will provide empirical significance first to the owners of SMEs in Ghana to appreciate EO, their social capital networks and how they can use that to garner resources from their own internal and internal networks and government support policies to their advantage, to policy makers like government and nongovernmental organisations with vested interest in the survival, growth and performance of SMEs to introduce more good policies to promote the growth and performance of existing and new businesses, and finally to practitioners to understanding the vital roles of social capital networks and government support policies on SMEs performance. This study will fill the knowledge and empirical gaps relating to this topic, contribute to academia in the field of entrepreneurship management, and finally make suggestions for further research that can validate the proposed framework empirically.

\section{References}

Abili, K., \& Faraji, H. (2009). A comparative study on organizational social capital in faculties of Humanities. Social and Behavioral Sciences at University of Tehran. Tehran, Iran.

Abor, J., \& Quartey, P. (2010). Issues in SME development in Ghana and South Africa. International Research Journal of Finance and Economics, 39, 218-228.

Acar, A. Z., \& Özşahin, M. (2018). The relationship among strategic orientations, organizational 
innovativeness, and business performance. International Journal of Innovation Management, 22 (01), 1-27. https://doi.org/10.1142/ S13639196 18500093

Acheampong, G., Odoom, R., Anning-Dorson, T., \& Anim, P. A. (2018). Resource access mechanisms in networks and SME survival in Ghana. Journal of Enterprising Communities: People and Places in the Global Economy, 2(5), 611-631. https://doi.org/10.1108/JEC-08-2017-0072

Adler, P. S., \& Kwon, S. W. (2002). Social capital: Prospects for a new concept. Academy of Management Review, 27(1), 17-40.

Agyapong, F. O., Agyapong, A., \& Poku, K. (2017). Nexus between social capital and performance of micro and small firms in an emerging economy: The mediating role of innovation. Cogent Business \& Management, 4(1), 1-20. https://doi.org/ 10.1080/23311975.2017.1309784

Ahimbisibwe, G., \& Abaho, E. (2013). Export entrepreneurial orientation and export performance of smes in Uganda. Global Advanced Research Journal of Management and Business Studies, 2 (1), 056-062.

Akugri, M. S., Bagah, D. A., \& Wulifan, J. K. (2015). The contributions of small and medium scale enterprises to economic growth: A cross-sectional study of Zebilla in the Bawku West District of Northern Ghana. European Journal of Business and Management, 7(9), 262-274.

Aladejebi, \& Olufemi, A. (2018). Predictors of firm performance among selected SMEs in Lagos, Nigeria. International Journal of Applied Reserach, 4(6), 08-17.

Alembummah, A. B. (2015). Entrepreneurial orientation and sme growth: A study of the food processing sector of Ghana. Doctoral dissertation. University of Ghana.

Alguezaui, S., \& Filieri, R. (2010). Investigating the role of social capital in innovation: Sparse versus dense network. Journal of Knowledge Management, 14(6), 891-909.

Alimo, M. T. (2015). The experiences of successful small business owners in Ghana. Doctoral Dissertation. Retrieved from ProQuest Dissertations and Theses database. (UMI No. 3706325)

Al Mamun, A., Rajennd, A., Muniady, L., Permarupa, P. Y., Zainol, N. R. B., Nawi, N. B. C., \& Malarvizhi, C. A. (2016). Social capital and entrepreneurial competencies: A study among women micro-entrepreneurs in Malaysia. The Journal of Developing Areas, 50(5), 363-370.
Ambad, S. N. A., \& Wahab, K. A. (2013). Entrepreneurial orientation among large firms in Malaysia: Contingent effects of hostile environments. International Journal of Business and Social Science, 4(16), 96-107.

Amin, M. (2015). The effect of entrepreneurship orientation and learning orientation on smes' performance: An SEM-PLS approach. Journal for International Business and Entrepreneurship Development, 8(3), 215-230.

Anderson, B. S., Kreiser, P. M., Kuratko, D. F., Hornsby, J. S., \& Eshima, Y. (2015). Reconceptualizing entrepreneurial orientation. Strategic Management Journal, 36(10), 1579-1596.

Anderson, A. R., \& Miller, C. J. (2003). “Class matters": Human and social capital in the entrepreneurial process. The Journal of Socio-Economics, 32(1), $17-36$.

Anlesinya, A., Eshun, P., \& Bonuedi, A. (2015). Entrepreneurial orientation dimensions and profitability nexus: Evidence from micro enterprises in the retail sector in a developing country. International Journal of Small Business and Entrepreneurship Research, 3(7), 79-87.

Arafah, W., Batara, R. R., \& Hady, H. (2018). Antecedents and consequence of entrepreneurial strategic orientation in micro business unit in Jakarta. International Journal of Entrepreneurship, 22(2), $1-7$.

Arshad, A. S., Rasli, A., Arshad, A. A., \& Zain, Z. M. (2014). The impact of entrepreneurial orientation on business performance: A study of technologybased smes in Malaysia. Procedia-social and behavioral sciences, 130, 46-53.

Asare, A. (2014). Strengthening innovation performance among sme's in Tema Metropolitan of Ghana. OIDA International Journal of Sustainable Development, 7(07), 19-28.

Bamfo, B. A., \& Kraa, J. J. (2019). Market orientation and performance of small and medium enterprises in Ghana: The mediating role of innovation. Cogent Business \& Management, 6(1), 1605703. https://doi.org/10.1080/23311975.2019.1605703

Barney, J. B. (1991). Firm resources and sustained competitive advantage. Journal of Management, 17(1), 99-120.

Barr, A. (2000). Social capital and technical information flows in the Ghanaian manufacturing sector. Oxford Economic Papers, 52(3), 539-559.

Batjargal, B. (2003). Social capital and entrepreneurial performance in Russia: A longitudinal study. Organization studies, 24(4), 535-556. 
Bature, S. W., Sallehuddin, R. M., Rosli, N. A., \& Saad, S. (2018). Proactiveness, Innovativeness

and Firm Performance: The Mediating Role of Organizational Capability. Academy of Strategic Management Journal.

Bhagavatula, S., Elfring, T., Van Tilburg, A., \& Van De Bunt, G. G. (2010). How social and human capital influence opportunity recognition and resource mobilization in India's handloom industry. Journal of Business Venturing, 25(3), 245-260.

Boateng, F. G., Nortey, S., Asamanin Barnie, J., Dwumah, P., Acheampong, M., \& AckomSampene, E. (2016). Collapsing microfinance institutions in Ghana: An account of how four expanded and imploded in the Ashanti region. International Journal of African Development, $3(2), 37-62$.

Boohene, R. (2018). Entrepreneurial orientation, strategic orientation and performance of small family firms in the Kumasi Metropolis. Academy of Entrepreneurship Journal, 24(2), 1-16.

Bloch, H., \& Bhattacharya, M. (2016). Promotion of innovation and job growth in small-and mediumsized enterprises in Australia: Evidence and policy issues. Australian Economic Review, 49(2), 192199.

Bourdieu, R (1977). Symbolic power. In D. Gleason (Ed.), Identity and structure: Issues in the sociology of education (pp. 112-119). Dimiffield, UK: Nefferton.

---.. (1986). The forms of capital. In J. G. Richardson (Ed.), Handbook of theory and research for the sociology of education (pp. 241258). Westport, CT: Greenwood Press.

Brush, C. G., \& Chaganti, R. (1999). Businesses without glamour? An analysis of resources on performance by size and age in small service and retail firms. Journal of Business Venturing, 14(3), 233-257.

Cai, S., Jun, M., \& Yang, Z. (2010). Implementing supply chain information integration in China: The role of institutional forces and trust. Journal of Operations Management, 28(3), 257-268.

Carree, M. A., \& Thurik, A. R. (2005). Understanding the role of entrepreneurship for economic growth (No. 1005). Papers on Entrepreneurship, Growth and Public Policy. Retrieved from https://www.econstor.eu/bitstream/10419/20001/1 12005-10.pdf

Chen, M. J., \& Hambrick, D. C. (1995). Speed, stealth, and selective attack: How small firms differ from large firms in competitive behavior. Academy of Management Journal, 38(2), 453-482.
Chirico, F., \& Salvato, C. (2008). Knowledge integration and dynamic organizational adaptation in family firms. Family Business Review, 21(2), 169-181.

Choi, S. B., Kim, K., Ullah, S. E., \& Kang, S. W. (2016). How transformational leadership facilitates innovative behavior of Korean workers. Personnel Review, 45, 459-479. https://doi.org/10.1 108/PR03-2014-0058

Coleman, J. S. (1988). Social capital in the creation of human capital. The American Journal of Sociology, 94, 95-120.

- (1990). Foundations of social theory. Cambridge: Harvard University Press.

Coulthard, M. (2007). The role of entrepreneurial orientation on firm performance and the potential influence of relational dynamism. Working Paper Series. Department of Management Monash University.

Covin, J. G., Green, K. M., \& Slevin, D. P. (2006). Strategic process effects on the entrepreneurial orientation-sales growth rate relationship. Entrepreneurship Theory and Practice, 30(1), 57-81. https://doi.org/10.1177/104225879101600102.

Covin, J. G., \& Slevin, D. P. (1986). The development and testing of an organizational-level entrepreneurship scale. In R. Ronstadt, J. A. Hornaday, R. Peterson, and K. H. Vesper (Eds.), Frontiers of entrepreneurship research 1986, (pp. 628-639). Center for Entrepreneurial Studies, Wellesley, MA, Babson College. ---. (1989). Strategic management of small firms in hostile and benign environments. Strategic Management Journal, 10(1), 75-87.

-----. (1991). A conceptual model of entrepreneurship as firm behavior. Entrepreneurship: Theory and Practice, 16(1), 7-24.

Covin, J. G., \& Wales, W. J. (2012). The measurement of entrepreneurial orientation. Entrepreneurship theory and practice, 36(4), 677-702.

Dato-on, M. C., Banerjee, S., \& Roy, M. (2018). Innovation support and small-firm performance in India: A social capital perspective. Thunderbird International Business Review, 60(5), 797-807.

De Clercq, D., Dimov, D., \& Thongpapanl, N. (2013). Organizational social capital, formalization, and internal knowledge sharing in entrepreneurial orientation formation. Entrepreneurship Theory and Practice, 37(3), 505-537.

Dess, G. G., Lumpkin, G., \& Covin, J. G. (1997). Entrepreneurial strategy making and firm performance: Tests of contingency and configurational models. Strategic Management Journal 18(9), 677-695. 
Duru, I. U., Ehidiamhen, P. O., \& Chijioke, A. N. (2018). Role of entrepreneurial orientation in the performance of small and medium enterprises: Evidence from federal capital territory, Abuja, Nigeria. Asian Journal of Economics, Business and Accounting, 6(1), 1-21.

Dutta, D. K., Gupta, V. K., \& Chen, X. (2016). A tale of three strategic orientations: A moderated-mediation framework of the impact of entrepreneurial orientation, market orientation, and learning orientation on firm performance. Journal of Enterprising Culture, 24(03), 313-348.

Egena, O., Wombo, D. N., Theresa, E. E., \& Bridget, M. N. (2014). Institutional support for small and medium enterprises in Nigeria: An empirical investigation. International Journal of Economy, Management and Social Sciences, 3(9), 481-489.

Elfring, T., \& Hulsink, W. (2003). Networks in entrepreneurship: The case of high-technology firms. Small Business Economics, 21(4), 409-422.

Eniola, A. A., \& Entebang, H. (2015). Government policy and performance of small and medium business management. International Journal of Academic Research in Business and Social Sciences, 5(2), 237-248.

Fadda, N. (2018). The effects of entrepreneurial orientation dimensions on performance in the tourism sector. New England Journal of Entrepreneurship, 21(1), 22-44. https://doi.org/10.1108/ NEJE -03-2018-0004

Fatoki, O. (2012). The impact of entrepreneurial orientation on access to debt finance and performance of small and medium enterprises in South Africa. Journal of social sciences, 32(2), 121-131.

Fukuyama, F. (1995) Trust: The social virtues and the creation of prosperity. New York, NY: Free Press.

Gathenya, J. W., Bwisa, H. M., \& Kihoro, J. M. (2011). Interaction between women entrepreneurs' age and education on business dynamics in small and medium enterprises in Kenya. International Journal of Business and social science, 2(15), 265272.

Gathungu, J. M., Aiko, D. M., \& Machuki, V. N. (2014). Entrepreneurial orientation, networking, external environment, and firm performance: A critical literature review. European Scientific Journal, 10(7), 335-357.

Gedajlovic, E., Honig, B., Moore, C. B., Payne, G. T., \& Wright, M. (2013). Social capital and entrepreneurship: A schema and research agenda.
Entrepreneurship Theory and Practice, 37(3), 455 $-478$.

Gharakhani, D., \& Mousakhani, M. (2012). Knowledge management capabilities and smes' organizational performance. Journal of Chinese Entrepreneurship, 4(1), 35-49. https://doi.org/10.1108/1756139 1211200920

Global Entrepreneurship Monitor (GEM) (2013), Global Entrepreneurship Monitor (GEM) 2013 Global Report. Retrieved from https://www.gemconsortium.org/report/gem-2013-global-report

Granovetter, M. (1985). Economic action and social structure: The problem of embeddedness. American Journal of Sociology, 91(3), 481-510.

(1995). The economic sociology of firms and entrepreneurs. In A. Portes (Ed.), The econonzic sociology of immigration (pp. 128-165). New York: Russell Sage.

Grant, E. H. C., Muths, E., Katz, R. A., Canessa, S., Adams, M. J., Ballard, J. R., \& Harris, M. C. (2017). Using decision analysis to support proactive management of emerging infectious wildlife diseases. Frontiers in Ecology and the Environment, 15(4), 214-221.

Gunday, G., Ulusoy, G., Kilic, K., \& Alpkan, L. (2011). Effects of innovation types on firm performance. International Journal of Production Economics, 133(2), 662-676.

Hameed, I., \& Ali, B. (2011). Impact of entrepreneurial orientation, entrepreneurial management and environmental dynamism on firm's financial performance. Journal of Economics and Behavioral Studies, 3(2), 101-114.

Hao, S., \& Song, M. (2016). Technology-driven strategy and firm performance: Are strategic capabilities missing links? Journal of Business Research, 69(2), 751-759.

Hayat, A., Latif, A., Humayon, A. A., Ahmed, M., \& Azeem, M. (2019). The mediating role of entrepreneurial leadership in the relationship between entrepreneurial orientation and firm performance of icts smes. Journal of Multidisciplinary Approaches in Science, 5(1), 16-23.

Heidenreich, S., \& Handrich, M. (2015). What about passive innovation resistance? Investigating adoption-related behavior from a resistance perspective. Journal of Product Innovation Management, 32(6), 878-903. https://doi.org/10.1111/ jpim. 12161

Hongyun, T., Kankam, W. A., Appiah-Twum, F., \& Akolgo, I. G. (2019). Effect of Social Capital on 
Firm Performance: The Role of Entrepreneurial Orientation and Dynamic Capability. International Review of Management and Marketing, 9(4), 63.

Hoque, A. S. M. M., \& Awang, Z. (2019). Does gender difference play moderating role in the relationship between entrepreneurial marketing and Bangladeshi sme performance? Accounting, 5(1), 35-52.

Hoque, A. S. M. M., Siddiqui, B. A., Awang, Z. B., \& Baharu, S. M. A. T. (2018). Exploratory factor analysis of entrepreneurial orientation in the context of Bangladeshi small and medium enterprises (smes). European Journal of Management and Marketing Studies, 3(2), 81-94. https:// doi.org/10.5281/zenodo.1292331

Hughes, M., \& Morgan, R. E. (2007). Deconstructing the relationship between entrepreneurial orientation and business performance at the embryonic stage of firm growth. Industrial Marketing Management, 36(5), 651-661.

Justine, A., Anthony, L., \& Max, C. (2005). The impact of entrepreneurial orientation on the Australian automotive component industry. Working Paper Series. Department of Management Monash University.

Kanini, K. S., \& Muathe, S. M. (2019). Nexus between social capital and firm performance: A critical literature review and research agenda. International Journal of Business and Management, 14 (8), 70-82. https://doi.org/10.5539/ijbm.v14n8p70

Kirzner, I. (1973). Competiotion \& entrepreneurship. Chicago: University of Chicago Press.

Knight, H. F. (1921). Risk, uncertainty and profit. Washington, DC: Beard Books.

Kombo, H. K., K'Obonyo, P., \& Ogutu, M. (2015). Knowledge strategy and performance of manufacturing firms in Kenya. Journal of Business \& Economic Policy, 2(3), 198-207.

Kosa, A., Mohammad, I., \& Ajibie, D. (2018). Entrepreneurial orientation and venture performance in Ethiopia: The moderating role of business sector and enterprise location. Journal of Global Entrepreneurship Research, 8(25), 1-17. https://doi. org/10.1186/s40497-018-0110-x

Krack-Hardt, D., \& Hanson, J. (1993, July-August). Informal networks: The company behind the chart. Harvard Business Review, 71 (4), 104-111.

Kreiser, P., Marino, L., Kuratko, D., \& Weaver, K.M. (2013). Disaggregating entrepreneurial orientation: The non-linear impact of innovativeness, proactiveness and risk-taking on sme performance. Small Business Economics, 40(2), 273-291.
Kreiser, P. M., Marino, L. D., \& Weaver, K. M. (2002). Assessing the psychometric properties of the entrepreneurial orientation scale: A multi-country analysis. Entrepreneurship theory and practice, 26(4), 71-93.

Kropp, F., Lindsay, N. J., \& Shoham, A. (2008). Entrepreneurial orientation and international entrepreneurial business venture startup. International Journal of Entrepreneurial Behavior \& Research, 14(2), 102-117. https://doi.org/10.1108/13552550 810863080

Kusi, A., Opata, C. N., \& Narh, T. W. J. (2015). Exploring the factors that hinder the growth and survival of small businesses in Ghana (a case study of small businesses within Kumasi metropolitan area). American Journal of Industrial and Business Management, 5(11), 705.

Kusumawardhani, A., McCarthy, G., \& Perera, N. (2009). Framework of entrepreneurial orientation and networking: A study of smes performance in a developing country. Proceedings of the Australian and New Zealand Academy of Management Conference (pp. 1-16). Adelaide, Australia: Australian and New Zealand Academy of Management.

Landstrom, H. (2005). A history of entrepreneurship and small business research. In H. Landstrom (Ed.), Pioneers in entrepreneurship and small business research. Springer Science Business Media Inc.

Lee, J. H., Sohn, S. Y., \& Ju, Y. H. (2011). How effective is government support for Korean woman entrepreneurs in small and medium enterprise? Journal of Small Business Management, 49(4), 599-616.

Lim, S. (2008). Entrepreneurial orientation and the performance of service business. Retrieved from http://www.decisionscience.org/Proceedings/DSI2 008/docs/392- 9586.pdf]

Lin, N., \& Dumin, M. (1986). Access to occupations through social ties. Social Networks, 8(4), 365385. https://psycnet.apa.org/doi/10.1016/03788733(86)90003-1

Lo, M. C., Wang, Y. C., Wah, C. R. J., \& Ramayah, T. (2016). Fatores críticos de sucesso para o desempenho organizacional de PMEs na Malásia: Uma abordagem parcial de mínimos quadrados. Revista Brasileira de Gestão de Negócios-RBGN, 18(61), 370-391.

Lomberg, C., Urbig, Stöckmann, C., Marino, L.D., \& Dickson, P.H. (2017). Entrepreneurial orientation: The dimensions' shared effects in explaining firm 
performance. Entrepreneurship Theory and Practice, 41, 973-998.

Lumpkin, G. T., \& Dess, G. G. (1996). Clarifying the entrepreneurial orientation construct and linking it to performance. Academy of Management Review, 21(1), 135-172.

- (2001). Linking two dimensions of entrepreneurial orientation to firm performance: The moderating role of environment and industry life cycle. Journal of Business Venturing, 16(5), 429451. http://doi.org/10.1016/S0883-9026(00)000483.

-. (2006). The effect of simplicity on the strategy performance relationship: A note. Journal of Management Studies, 43(7), 1583-1604.

Lyon, D. W., Lumpkin, G. T. \& Dess, G. G. (2000). Enhancing entrepreneurial orientation research: Operationalizing and measuring a key strategic decision making process. Journal of Management, 26, 1055-1085.

Lysons, K., \& Farrington, B. (2012). Purchasing and supply chain management. $8^{\text {th }}$ Edition. Harlow, UK: Pearson Education Limited.

Mahmood, R., \& Hanafi, N. (2013). Entrepreneurial orientation and business performance of womenowned small and medium enterprises in Malaysia: Competitive advantage as a mediator. International Journal of Business and Social Science, 4(1), 8290.

Mahmoud, M. A. (2011). Market orientation and business performance among smes in Ghana. International Business Research, 4(1), 241-251. DOI: 10.5539/ibr.v4n1p241

Mair, J., \& Marti, I. (2005). Social entrepreneurship research: A source of explanation, prediction and delight. Working Paper 546, IESE Business School, University of Nevada.

Mamun, A. A., Muhammad, N. M. N., \& Ismail, M. B. (2017). Absorptive capacity, innovativeness and the performance of micro-enterprises in Malaysia. Vision, 21(3), 243-249. https://doi.org/10. 1177\%2F0972262917716729

Mason, M. C., Floreani, J., Miani, S., Beltrame, F., \& Cappelletto, R. (2015). Understanding the impact of entrepreneurial orientation on smes' performance: The role of the financing structure. Procedia Economics and Finance, 23, 1649-1661.

Mensah, E. (2018). We are suffering: Ghana's entrepreneurs cry. Retrieved from Ghana myjoyonline.com.

Mihaela H. (2017). Drivers of firm performance: Exploring quantitative and qualitative approaches.
Studies in Business and Economics, 12(1), 79-84. doi 10.1515/Sbe-2017-0006

Miles R. E., \& Snow C. C. (1978). Organisation: Strategy, structure and process. New York, NY: McGraw-Hill.

Miller, D. (1983). The correlates of entrepreneurship in three types of firms. Management Science, 29(7), 770-791.

Miller, D., \& Chen, M. J. (1994). Sources and consequences of competitive inertia: A study of the US airline industry. Administrative Science Quarterly, 39(1), 1-23.

(1996). The simplicity of competitive repertoires: An empirical analysis. Strategic Management Journal, 17(6), 419-439.

Miller, D., \& Friesen, P. H. (1983). Strategy-making and environment: The third link. Strategic Management Journal, 4(3), 221-235.

Mohammed A. (June 7, 2017). 75\% of businesses in Ghana fail after 3 years. Retrieved from Daily Guide Africa; dailyguideafrica.com, $7^{\text {th }}$ June, 2017. . (June 18, 2018). Rate of business failure in Ghana is unacceptable. Retrieved from Ghana Business and Financial Times; ggea.net.

Mohammed, S. M., Ricardo, B., \& Harry, E. (2014). Entrepreneurial orientation and financial performance of Nigerian smes: The moderating role of environment. Retrieved from https://www. academia.edu/8937395/A

Morris, M. H., Kuratko, D. F., \& Covin, J. G. (2008). Corporate entrepreneurship and innovation. $2^{\text {nd }}$ Ed. Mason, OH, USA: Thomson Higher Education.

Nahapiet, J., \& Ghoshal, S. (1998). Social capital, intellectual capital, and the organizational advantage. Academy of Management Review, 23(2), 242-266.

Nasip, S., Fabeil, N. F., Buncha, M. R., Hui, J. N. L., Sondoh, S., \& Abd Halim, D. (2017). Influence of entrepreneurial orientation and social capital on business performance among women entrepreneurs along West Coast Sabah Malaysia. Paper presented at the Proceedings of International Conference on Economics.

Ntiamoah, E. B., Li, D., \& Kwamega, M. (2016). Impact of government and other institutions' support on performance of small and medium enterprises in the agribusiness sector in Ghana. American Journal of Industrial and Business Management, 6 , 558-567. http://dx.doi.org/10.4236/ajibm.2016. 65052 
Ofori, D., \& Sackey, J. (2010). Assessing social capital for organisational performance: Initial exploratory insights from Ghana. Organizations and markets in emerging economies, 1(2), 71-91.

Omisakin, O. M., Nakhid, C., Littrell, R., \& Verbitsky, J. (2016). Entrepreneurial orientation among migrants and small and medium enterprises. Journal of Business Administration Research, 5(1), 7-22. http://doi.org/10.5430/jbar.v5n1p7

Omrane, A. (2015). 'Entrepreneurs' social capital and access to external resources: The effects of social skills. International Journal of Entrepreneurship and Small Business, 24(3), 357-382.

Ong, W. J., \& Ismail, B. H. (2012). Entrepreneurial traits and firm serendipity-seeking on SMEs' performance: The effect of firm size. Journal of Enterprising Culture (JEC), 20(3), 265-286.

Onugu, B. A. N. (2005). Small and medium enterprises (smes) in Nigeria: Problems and prospects. Unpublished Dissertation for a Doctor of Philosophy in Management Award. St. Clements University, Nigeria

Onuoha, B. C. (2012). The relationship between government policies on smes and development: A study of selected countries. AFRREV IJAH: An International Journal of Arts and Humanities, 1(3), 288-309.

Otieno, S., Bwisa, H. M., \& Kihoro, J. M. (2012). Influence of entrepreneurial orientation on Kenya's manufacturing firms operating under East African regional integration. International Journal of Learning \& Development, 2(1), 299-320.

Palmer, C., Niemand, T., Stöckmann, C., Kraus, S., \& Kailer, N. (2019). The interplay of entrepreneurial orientation and psychological traits in explaining firm performance. Journal of Business Research, 94, 183-194.

Pett, T. L., \& Wolff, J. A. (2010). Sme performance: The role of learning orientation and its relationship to market orientation and entrepreneurial orientation. In ICSB World Conference Proceedings (p. 1). International Council for Small Business (ICSB).

Porter, M. (1985). Creating and sustaining superior performance: Competitive Advantage. New York, NY: Free Press.

Pranowo, A. S., Mulyadi, H. H., Siregar, Z. M. E., \& Hendayana, Y. (2018). The influence of entrepreneurship orientation and management capability on performance of small and medium enterprises in Bogor. Proceedings of the 2nd
Global Conference on Business, Management and Entrepreneurship (GC-BME 2017), August 9, 2017, Universitas Airlangga, Surabaya, Indonesia

Putnam, R. (1993). Making democracy work: Civic traditions in modern Italy. Princeton, NJ: Princeton University Press.

-----. (2000) Bowling alone: The collapse and revival of America's civic community. New York, NY: Simon and Schuster.

Rass, M., Dumbach, M., Danzinger, F., Bullinger, A. C., \& Moeslein, K. M. (2013). Open innovation and firm performance: The mediating role of social capital. Creativity and innovation management, 22(2), 177-194.

Rauch, A., Wiklund, J., Lumpkin, G. T., \& Frese, M., (2009). Entrepreneurial orientation and business performance: An assessment of past research and suggestions for the future. Entrepreneurship Theory and Practice, 33(3), 761-781.

Rezaei, J., \& Ortt, R. (2018). Entrepreneurial orientation and firm performance: The mediating role of functional performances. Management Research Review, 41(7), 878-900. https://doi.org/10. 1108/MRR-03-2017-0092

Roberson, Q., \& Williamson, I. (2012). Justice in selfmanaging teams: The role of social networks in the emergence of procedural justice climates. The Academy of Management Journal, 55(3), 685-701.

Rowley, T., Behrens, D., \& Krackhardt, D. (2000). Redundant governance structures: An analysis of structural and relational embeddedness in the steel and semiconductor industries. Strategic Management Journal, 21(3), 369-386.

Rua, O., França, A., \& Ortiz, R. F. (2018). Key drivers of smes export performance: the mediating effect of competitive advantage. Journal of Knowledge Management, 20(2), 237-256.

Saberi, M., \& Hamdan, A. (2018). The moderating role of governmental support in the relationship between entrepreneurship and economic growth: A study on the GCC countries. Journal of Entrepreneurship in Emerging Economies, 11(2), 200216. https://doi.org/10.1108/JEEE-10-2017-0072

Salehuddin, K. (2009). The acquisition of numeral classifiers by Malay children. Doctoral Dissertation. University of Western Sydney, Australia.

Schumpeter, J. A. (1942). Capitalism, socialism, and democracy. New York: Harper \& Brothers.

Semrau, T., Ambos, T., \& Kraus, S. (2016). Entrepreneurial orientation and SME performance across societal cultures: An international study. Journal of Business Research, 69(5), 1928-1932. 
Shan, P., Song, M., \& Ju, X. (2016). Entrepreneurial orientation and performance: Is innovation speed a missing link? Journal of Business Research, 69(2), 683-690.

Shu, C., De Clercq, D., Zhou, Y., \& Liu, C. (2019). Government institutional support, entrepreneurial orientation, strategic renewal, and firm performance in transitional China. International Journal of Entrepreneurial Behavior \& Research, 25(3), 433-456. https://doi.org/10.1108/IJEBR-07-20180465

Smith, K. G., Young, G., Becerra, M., \& Grimm, C. M. (1996). An assessment of the validity of competitive dynamic research. Academy of Management Proceedings, 1996(1), 61-65.

Soares, A. D. C., Moeljadi, Rohman, F., \& Solimun (2014). Effect of entrepreneurial orientation on business performance moderated by government policy (Study on smes in Timor Leste). International Journal of Business and Management Invention, 3(8), 64-71.

Stuart, T. E. (2000). Interorganizational alliances and the performance of firm: A study of growth and innovation rates in a high-technology industry. Strategic Management Journal, 21(8), 791-811.

Tang, J., Tang, Z., \& Katz, J. A. (2014). Proactiveness, stakeholder-firm power difference, and product safety and quality of Chinese smes. Entrepreneurship Theory and Practice, 38(5), 1-29.

Tundui, C., \& Tundui, H. (2013). An empirical analysis of social capital and enterprise performance in Tanzania: The case of women owned businesses. International Journal of Developing Societies, 2(1), 50-60.

Tsai, W., \& Ghoshal, S. (1998). Social capital and value creation: The role of intrafirm networks. Academy of Management Journal, 41(4), 464-476.

Tsao, S. M., \& Chen, G. Z. (2012). The impact of internationalization on performance and innovation: The moderating effects of ownership concentration. Asia Pacific Journal of Management, 29 (3), 617-642.

Tzelepis, D., \& Skuras, D. (2004), The effects of regional capital subsidies on firm performance: An empirical study. Journal of Small Business and Enterprise Development, 11(1), 121-129. https ://doi.org/10.1108/14626000410519155

Uddin, R., Bose, T. K., \& Yousuf, S. (2014). Entrepreneurial orientation (eo) and performance of business in Khulna City, Bangladesh. Journal of Small Business \& Entrepreneurship, 27(4), 343352.

Uzzi, B., \& Lancaster, R. (2003). Relational embeddedness and learning: The case of bank loan managers and their clients. Management Science, 49, 383-99.

Venkatraman, N. (1989). Strategic orientation of business enterprises: The construct, dimensionality, and measurement. Management Science, 35(8), 942-962.

Wales, W. J., Patel, P. C., \& Lumpkin, G. T. (2013). In pursuit of greatness: Ceo narcissism, entrepreneurial orientation, and firm performance variance. Journal of Management Studies, 50(6), 10411069.

Walter, A., Auer, M., \& Ritter, T. (2006). The impact of network capabilities and entrepreneurial orientation on university spin-off performance. Journal of Business Venturing, 21(4), 541-567.

Wang, Y., \& Poutziouris, P. (2010). Entrepreneurial risk taking: Empirical evidence from UK family firms. Entrepreneurial Behavior \& Research, 16(5), 370388.

Wijethunge, W. A. D. S., \& Pushpakumari, M. D. (2013). Entrepreneurial orientation and business performance of small and medium scale enterprises of western province of Sri Lanka. Kelaniya Journal of Management, 2(2), 51-67. DOI: http://doi.org/ $10.4038 / \mathrm{kjm} . v 2 \mathrm{i} 2.6550$

Wiklund, J., \& Shepherd, D. (2005). Entrepreneurial orientation and small business performance: A configurational approach. Journal of Business Venturing, 20(1), 71-91.

Wiklund, J., Patzelt, H., \& Shepherd, D. A. (2009). Building an integrative model of small business growth. Small Business Economics, 32(4), 351374.

Wong, S. K. S. (2014). Impacts of environmental turbulence on entrepreneurial orientation and new product success. European Journal of Innovation Management, 17(2), 229-249.

Woolcock, M. (2001). The place of social capital in understanding social and economic outcomes. Canadian Journal of Policy Research, 2(1), 11-17.

Woolcock, M., \& Sweetser, A. T. (2002). Bright ideas: Social capital-the bonds that connect. $A D B$ Review, 34(2), 26-27.

Yang, C. W. (2008). The relationships among leadership styles, entrepreneurial orientation and firm performance. Managing Global Transitions, 6(3), 257275.

Zahra, S. A., \& George, G. (2002). International entrepreneurship: The current status of the field and future research agenda. Strategic Entrepreneurship: Creating a New Mindset. Strategic Management Series, Oxford, pp. 255-288. Research Collection Lee Kong Chian School of Business. 